his goals was to propose a philosophical basis for a critique of the social criticism of Christopher Lasch and Lewis Mumford.

\title{
American Historical Association: Latin American and European Labor History
}

\author{
Leslie Ann Schuster \\ Wabash College
}

The December 1991 meeting of the American Historical Association included few panels on European labor history. At a session on "International Economies and Indian Labor in Turn-of-the-Century Latin America," Peter Linder (Washington State University) investigated Indian forced labor in Venezuela. Labor shortages induced hacendados in the Sur del Lago zuliano to enslave the Guajiro Indians. Although Indian slaves became "the mainstay of the agricultural labor force" by the 1920s, state officials regarded slavery as necessary for economic development and assimilation and chose only to minimize abuses. Erick D. Langer (Carnegie Mellon University) examined two contrasting labor systems in Argentina: The Chaco tribes were coerced to work on the sugar cane fields while the Chriguano Indians chose to migrate to the plantations. Coercion proved ineffective among the Chiriguanos but material enticements and political oppression imposed by new settlers led them to migrate. Michael Stanfield (University of New Mexico) also argued against characterizing Indians as victims of the international economy. While the search for rubber and quina in northwestern Amazonia dictated forced labor and transformed material and social relations, Indians did not remain passive victims. Instead, the culture and resources of indigenous tribes shaped their adaptation. Some tribes participated in trade, others used "primeval traditions to rescue culture," yet others attacked industrial outposts, and those tribes diminished in number by European diseases stole women members of other tribes to enhance social status.

The panel on "The International Character of Italian Immigrant Radicalism, 1870-1939" examined how political experiences in Italy shaped the activity of Italian immigrants in the United States. Fraser M. Ottanelli (University of South Florida-Lakeland) illustrated the relationship between workers' political activity in Italy and their antifascism in the United States. An analysis of the profession, political affiliation, and age of immigrants points to a correlation between labor and political activity in Italy and participation in the antifascist movement upon immigration. Ottanelli underscored the need for a generational examination of immigrant radicalism by showing that the antifascism of Italians raised in the U.S. in the 1930s emerged from different political experiences. Patrizia Sione (State 
University of New York-Binghamton) challenged the assumption that immigrants' political behavior was shaped by their experiences as a preindustrial workforce in Italy. On the contrary, the militance of Italian immigrants in Paterson, New Jersey developed in the transition from domestic to industrial production in the textile districts of Italy. In the transformation from worker-peasants to proletarians, workers developed a working-class identity. Their cultural heritage, which "valued anarchism, socialism, and organized unionism" and was intent on the emancipation of labor, informed their activity in Paterson. Donna R. Gabaccia (University of North Carolina-Charlotte) argued for research into political, as distinguished from labor, migration. The politics of Italian political migrants followed the history of reform and revolution in Italy: nationalists, followed by anarchists, socialists, and under fascism, communists. This paralleled a decline in upper- and middle-class migration so that by World War I political migrants came to "resemble labor migrants." Political migrants differed from labor migrants in choosing European destinations from where they could influence Italian politics. Gabaccia concluded with a call for further study of the connections between political migration and national migration policy.

\title{
American Historical Association: Women's Labor History
}

\author{
Kali A.K. Israel \\ University of Cincinnati
}

The 1992 meeting of the American Historical Association was notably lacking in panels dedicated to labor history, although many papers dealing with aspects of working-class political or cultural activity were included. A high proportion were concerned with the history of women workers and-the relationships between gender, work, class identity, and social change.

A session on "Narrative Authority and Women's Lives in Late 19th-Early 20th Century Britain: Middle-Class Women's Representations of Working-Class Women," chaired by Ian C. Fletcher, analyzed the interactions of middle- and working-class women. Kali Israel's "Working-Class Women as Selves and Others: Trade Unionism and Self-Creation in the Life of Emilia Dilke," and Polly Beals's "Imagining Women and Socialist Alternatives in Fabian Texts," considered the ways in which middle-class women engaged in struggles for meaningful public activity and political roles deployed representations of working-class women in their texts. Israel argued that Dilke's rhetorical strategies, as president of the Women's Trade Union League, emphasized that women workers were both like and unlike middle-class women, possessing their own perceptions, voices, and desires, but not completely "Other." Beals, however, found that Fabian women's portrayals of the working-class women of Lambeth in the 1920s for Round About a Pound a 